\title{
Assessment of Water and Proppant Quantities Associated with Petroleum Production from the Bakken and Three Forks Formations, Williston Basin Province, Montana and North Dakota, 2016
}

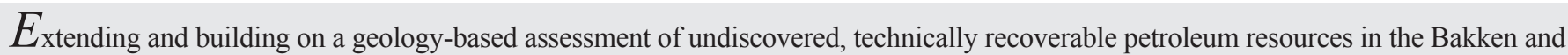
Three Forks Formations of the Williston Basin Province in Montana and North Dakota, the U.S. Geological Survey has estimated the water and proppant demands and water-production volumes associated with possible future development of those petroleum resources. The water and proppant assessment results are presented here, along with related drilling information and relevant water budget volumes for the region.

\section{Introduction}

The U.S. Geological Survey (USGS) has completed an assessment of water and proppant requirements and water production associated with the possible future production of undiscovered oil and gas resources in the Three Forks and Bakken Formations (Late Devonian to Early Mississippian) of the Williston Basin Province in Montana and North Dakota (fig. 1). This water and proppant assessment is directly linked to the geology-based assessment of the undiscovered, technically recoverable continuous oil and gas resources that is described by Gaswirth and others (2013), and it is the first of its kind conducted by the USGS.

The production of oil and gas from continuous accumulations, such as the Bakken and Three Forks Formations, is commonly made possible by hydraulic fracturing stimulation, which involves pumping fluids containing water and proppant (granular material, often sand, that is intended to hold open the newly generated fractures) into the petroleum reservoir to improve fluid-flow characteristics. Water is also used during the process of drilling a production well and cementing the well casing in place, and the horizontal wells that are often (but not always) involved with producing petroleum from continuous reservoirs typically require larger water volumes for drilling and cement than comparable vertical wells. When petroleum production commences, water is generally produced along with oil and gas. This produced water includes hydraulic fracturing water, which returns as "flowback water" early in the life of the well, and "formation water," which resides in or adjacent to the petroleum reservoir formation and is produced throughout the duration of petroleum production.

Between the time of the 2013 petroleum assessment (Gaswirth and others, 2013) and this water and proppant assessment (conducted in 2016 using data current up to August 2016), more than 6,000 additional production wells have been drilled in the Bakken and Three Forks Formations involving at least 22 billion gallons of water and 12 million tons of proppant used for hydraulic fracturing. Between January 2013 and August 2016, approximately 42 billion gallons of water, along with 1.3 billion barrels of oil, have been produced from these two formations.

\section{Assessment Approach and Input Values}

The USGS methodology for assessing the water and proppant requirements and water production associated with possible future production of oil and gas from continuous accumulations is described by Haines (2015). The methodology incorporates many elements of the USGS assessment approach for continuous petroleum accumulations (Charpentier and Cook, 2010), including estimated ultimate recovery of petroleum per well (EUR) and the input values and calculations for estimating the number of wells potentially associated with production of the petroleum in each assessment unit (AU). In addition, the water and

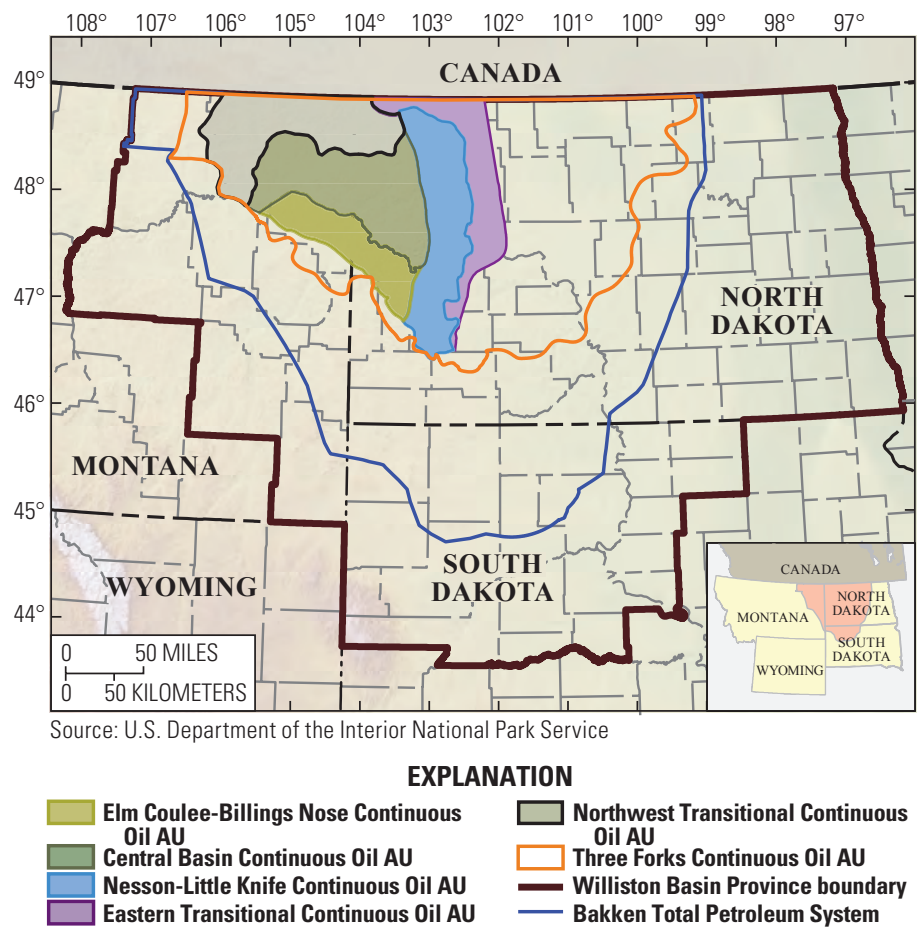

Figure 1. Map showing the Williston Basin Province, Bakken Total Petroleum System (TPS), the five Bakken continuous assessment units (AUs), and the Three Forks Formation continuous AU (these six AUs are all part of the Bakken TPS) in Montana and North Dakota. Modified from Gaswirth and others (2013).

proppant assessment methodology includes input values for the water per well for drilling and cement and for hydraulic fracturing treatment, the proppant-to-water ratio for hydraulic fracturing, the percentage of hydraulic fracturing water that returns as flowback, and the long-term water-to-oil or water-to-gas ratio. The long-term produced water-topetroleum ratio represents formation water (water that exists along with petroleum in the geologic formation) and the volume of water exceeding this ratio during the first few months after hydraulic fracturing is considered to be flowback water. A Monte Carlo approach provides probabilistic outputs based on probabilistic inputs (Haines, 2015).

This 2016 water and proppant assessment for the Bakken and Three Forks Formations incorporates the geologic information in the 2013 assessment of oil and gas in the Bakken and Three Forks Formations (Gaswirth and others, 2013; Gaswirth and Marra, 2015), and it uses the same values for EUR and the inputs that are part of the well count calculation. Gaswirth and others (2013) defined six AUs that 
are part of the Bakken Total Petroleum System: five continuous AUs for the Bakken Formation and one continuous AU for the Three Forks Formation (fig. 1). The 2013 petroleum assessment also included hypothetical conventional AUs for additional areas of the Bakken and Three Forks Formations, but those are not included in this water and proppant assessment because the water and proppant assessment methodology applies only to continuous petroleum resources.

We determined input values for the water and proppant assessment using analysis of data relating to water and proppant use and water production for the Bakken and Three Forks Formations from IHS Markit ${ }^{\mathrm{TM}}$ (2016) and data provided by the North Dakota Industrial Commission. All inputs are specified as ranges of possible values, rather than as single fixed values, to allow quantification of uncertainty throughout the assessment process. Selected assessment input values are shown in table 1.

Several assessment inputs describe quantities whose specific values are driven by technical choices made by oil and gas production companies. These inputs were assigned the same values for all AUs (table 1) based on the observation that similar technologies are being employed throughout the entire assessment area. Based on analysis of water use for hydraulic fracturing of wells producing from the Bakken and Three Forks Formations (IHS Markit, 2016), the water requirement per well for hydraulic fracturing treatment was estimated as a range that has a mean value of 4.17 million gallons. From the same data source, the proppant-to-water ratio for hydraulic fracturing treatments was estimated to have a mean value of 1.2 pounds of proppant per gallon of water. Based on trends reported for similar wells, the water requirement per well for drilling and cement was estimated to have a mean value of 150,000 gallons; data describing actual water use for the drilling and cementing of wells producing from the Bakken and Three Forks Formations are limited.

Monthly water and oil production data (IHS Markit, 2016) allow estimation of two different input values as described by Haines (2015): (1) the percent of hydraulic fracturing fluid that returns to the surface as flowback and (2) the long-term water-to-oil ratio for production over the life of the well. Based on spatial and temporal analysis of all available data for wells producing from the Bakken and Three Forks Formations, the input value indicating the percentage of hydraulic fracturing fluid that returns as flowback water was estimated to be the same for all AUs with a mean value of 6 percent. The long-term water-to-petroleum ratio was specified uniquely for each AU and for sweet-spot and non-sweetspot areas within each AU because this parameter is tied closely to reservoir characteristics, which vary considerably across the province. Geologic sweet spots were defined by Gaswirth and others (2013), and maps of the sweet spots are shown by Gaswirth and Marra (2015).

\section{Water and Proppant Assessment Results and Supporting Information}

Results from the 2016 USGS water and proppant assessment are shown in table 2. All assessment outputs are distributions that indicate the range of possible values and the table summarizes these with the 95th fractile (F95), 50th fractile or median (F50), 5th fractile (F5), and the mean value. Summing over all AUs, the mean estimated total water for drilling and cement is 5.9 billion gallons, the mean estimated water for hydraulic fracturing is 164.3 billion gallons, the mean estimated quantity of proppant for hydraulic fracturing is 101.3 million tons, the mean estimated total flowback water volume is 9.9 billion gallons, and the mean estimated total produced water is 414.5 billion gallons.

The fundamental assessment outputs (table 2) are estimates of the total water and proppant requirements and total water production associated with development of the entire undiscovered petroleum resource in the Bakken and Three Forks Formations of the Williston Basin Province. Future extraction of this oil resource, if it occurs, would take place with a rate and timing that are unknown. Table 3 provides additional information intended to help users understand questions involving the rate of oil development on an annual basis (the basis on which most water planning occurs). Specifically, the table shows the reported number of oil and gas wells drilled annually within each AU from 2011 to 2015 (IHS Markit, 2016) and estimated quantities of water and proppant associated with different scenarios for possible drilling rates. These water and proppant volume estimates are based on the mean values of the associated assessment input distributions.

To provide context for the water volumes in tables 2 and 3 , table 4 shows water quantities for other parts of the hydrologic system within each AU. These include the total water produced as part of oil and gas production (IHS Markit, 2016), total surface water and groundwater withdrawals (Maupin and others, 2014), and water use in four

Table 1. Selected input values for the water and proppant assessment. The "long-term produced water ratio" and flowback water volume are defined and discussed by Haines (2015).

[AU, assessment unit; Mgal, million gallons; lb/gal, pound per gallon; \%, percent; bbl, barrel]

\begin{tabular}{|c|c|c|c|c|}
\hline Assessment input value & Minimum & Mode & Maximum & Calculated mean \\
\hline \multicolumn{5}{|c|}{ Inputs common among all AUs, for geologic sweet-spot and non-sweet-spot areas } \\
\hline Water per well, for hydraulic fracturing treatment (Mgal) & 2.5 & 4.0 & 6.0 & 4.17 \\
\hline Proppant-to-water ratio, for hydraulic fracturing (lb/gal) & 1.0 & 1.2 & 1.5 & 1.2 \\
\hline Water per well, for drilling and cement (Mgal) & 0.10 & 0.15 & 0.20 & 0.15 \\
\hline Fraction of hydraulic fracturing treatment volume that returns as flowback water (\%) & 1 & 5 & 12 & 6 \\
\hline \multicolumn{5}{|c|}{ Inputs specified separately for each AU } \\
\hline \multicolumn{5}{|c|}{ Elm Coulee-Billings Nose Continuous Oil AU } \\
\hline Long-term produced water ratio, for geologic sweet-spot areas (bbl water per bbl oil) & 0.3 & 0.4 & 0.8 & 0.5 \\
\hline Long-term produced water ratio, for non-sweet-spot areas (bbl water per bbl oil) & 1.0 & 1.3 & 2.0 & 1.43 \\
\hline \multicolumn{5}{|c|}{$\begin{array}{ll} & \text { Central Basin Continuous Oil AU }\end{array}$} \\
\hline Long-term produced water ratio, for geologic sweet-spot areas (bbl water per bbl oil) & 0.75 & 0.90 & 1.20 & 0.95 \\
\hline Long-term produced water ratio, for non-sweet-spot areas (bbl water per bbl oil) & 1.2 & 1.5 & 1.8 & 1.5 \\
\hline \multicolumn{5}{|c|}{ Nesson-Little Knife Continuous Oil AU } \\
\hline Long-term produced water ratio, for geologic sweet-spot areas (bbl water per bbl oil) & 0.30 & 0.50 & 0.65 & 0.48 \\
\hline Long-term produced water ratio, for non-sweet-spot areas (bbl water per bbl oil) & 0.8 & 1.2 & 1.6 & 1.2 \\
\hline \multicolumn{5}{|c|}{$\begin{array}{ll}\text { Eastern Transitional Continuous Oil AU }\end{array}$} \\
\hline Long-term produced water ratio, for geologic sweet-spot areas (bbl water per bbl oil) & 0.25 & 0.4 & 1.1 & 0.58 \\
\hline Long-term produced water ratio, for non-sweet-spot areas (bbl water per bbl oil) & 1.5 & 2.0 & 3.5 & 2.3 \\
\hline \multicolumn{5}{|c|}{ Northwest Transitional Continuous Oil AU } \\
\hline Long-term produced water ratio, for geologic sweet-spot areas (bbl water per bbl oil) & 1.5 & 2.5 & 5.0 & 3.0 \\
\hline Long-term produced water ratio, for non-sweet-spot areas (bbl water per bbl oil) & 2.0 & 4.0 & 6.0 & 4.0 \\
\hline \multicolumn{5}{|c|}{ 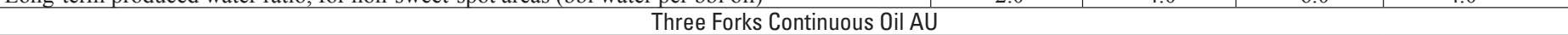 } \\
\hline Long-term produced water ratio, for geologic sweet-spot areas (bbl water per bbl oil) & 0.8 & 1.0 & 1.5 & 1.1 \\
\hline Long-term produced water ratio, for non-sweet-spot areas (bbl water per bbl oil) & 1.5 & 2.0 & 3.5 & 2.3 \\
\hline
\end{tabular}


Table 2. Assessment results showing resource requirements and production associated with production of continuous petroleum deposits in the Bakken Total Petroleum System, Williston Basin Province, Montana and North Dakota.

[F95 represents a 95-percent chance of at least the amount tabulated; other fractiles are defined similarly. Mgal, million gallons. Gray shading indicates not applicable]

\begin{tabular}{|c|c|c|c|c|c|c|c|c|c|c|c|c|c|c|}
\hline \multirow{3}{*}{$\begin{array}{l}\text { Total petroleum system } \\
\text { and assessment units (AUs) }\end{array}$} & \multirow{3}{*}{$\begin{array}{l}\text { Field } \\
\text { type }\end{array}$} & \multicolumn{13}{|c|}{ Estimated total requirement/production } \\
\hline & & \multicolumn{6}{|c|}{ Water for drilling (Mgal) } & \multicolumn{7}{|c|}{ Water for hydraulic fracturing (Mgal) } \\
\hline & & F95 & & & & F5 & Mean & & $=95$ & F50 & \begin{tabular}{l|l}
55 \\
\end{tabular} & & & Mean \\
\hline \multicolumn{15}{|c|}{ Bakken Total Petroleum System } \\
\hline Elm Coulee-Billings Nose Continuous Oil AU & Oil & 262 & \multicolumn{2}{|c|}{337} & \multicolumn{2}{|c|}{427} & 339 & \multicolumn{2}{|c|}{7,190} & 9,364 & \multicolumn{2}{|c|}{11,988} & & 9,440 \\
\hline Central Basin Continuous Oil AU & Oil & 703 & \multicolumn{2}{|c|}{846} & \multicolumn{2}{|c|}{1,014} & 851 & \multicolumn{2}{|c|}{19,364} & 23,522 & \multicolumn{2}{|c|}{28,433} & & 23,657 \\
\hline Nesson-Little Knife Continuous Oil AU & Oil & 576 & \multicolumn{2}{|c|}{698} & \multicolumn{2}{|r|}{840} & 701 & \multicolumn{2}{|c|}{15,864} & 19,391 & \multicolumn{2}{|c|}{23,580} & & 19,511 \\
\hline Eastern Transitional Continuous Oil AU & Oil & 401 & \multicolumn{2}{|c|}{500} & \multicolumn{2}{|r|}{622} & 504 & \multicolumn{2}{|c|}{10,892} & 13,880 & \multicolumn{2}{|c|}{17,674} & & 14,023 \\
\hline Northwest Transitional Continuous Oil AU & Oil & 152 & \multicolumn{2}{|c|}{330} & \multicolumn{2}{|c|}{568} & 341 & \multicolumn{2}{|c|}{4,197} & 9,159 & \multicolumn{2}{|c|}{15,880} & & 9,481 \\
\hline Three Forks Continuous Oil AU & Oil & 1,486 & \multicolumn{2}{|c|}{2,968} & \multirow{2}{*}{\multicolumn{2}{|c|}{5,535}} & 3,176 & \multirow{2}{*}{\multicolumn{2}{|c|}{41,248}} & 82,537 & \multicolumn{2}{|c|}{153,924} & & 88,208 \\
\hline Estimated total requirement/production & & & & & & & 5,912 & & & & & & & 64,320 \\
\hline \multirow{2}{*}{$\begin{array}{c}\text { Total petroleum system } \\
\text { and assessment units (AUs) }\end{array}$} & Proppan & or hydrauli & c fracturi & $g(10$ & ons) & & wback v & later (Mc & & & roduced $\mathrm{u}$ & water & Mga & \\
\hline & F95 & F50 & F5 & & & F95 & $\mathrm{F} 50$ & F5 & Mean & F95 & $\mathrm{F50}$ & $\mathbf{F}$ & & Mean \\
\hline & & $\mathrm{Bal}$ & kken Tot & $\mathrm{Pe}$ & bleur & m Syste & & & & & & & & \\
\hline Elm Coulee-Billings Nose Continuous Oil AU & 4,341 & 5,751 & 7,549 & & & 290 & 546 & 910 & 566 & 9,175 & 12,703 & & & 12,927 \\
\hline Central Basin Continuous Oil AU & 11,626 & 14,473 & 17,958 & & & 770 & 1,385 & 2,177 & 1,419 & 45,538 & 56,981 & & & 57,477 \\
\hline Nesson-Little Knife Continuous Oil AU & 9,541 & 11,928 & 14,864 & & & 638 & 1,142 & 1,804 & 1,171 & 27,091 & 35,793 & & & 36,119 \\
\hline Eastern Transitional Continuous Oil AU & 6,534 & 8,531 & 11,158 & & & 401 & 805 & 1,397 & 841 & 48,792 & 68,838 & & & 70,740 \\
\hline Northwest Transitional Continuous Oil AU & 2,574 & 5,629 & 9,866 & & & 208 & 520 & 1,092 & 569 & 12,021 & 27,804 & & & 29,681 \\
\hline Three Forks Continuous Oil AU & 25,185 & 50,759 & 95,469 & & & 1,967 & 4,751 & 10,512 & 5,291 & 92,650 & 192,666 & 374 & & 207,572 \\
\hline Estimated total requirement/production & & & & 101 & & & & & 9,857 & & & & & 414,516 \\
\hline
\end{tabular}

Table 3. Historical number of wells drilled in each assessment unit (AU) during each of the indicated years and quantities of water and proppant use and water production potentially associated with various possible future annual drilling rates.

[Mgal, million gallons. Gray shading indicates not applicable]

\begin{tabular}{|c|c|c|c|c|c|c|c|c|c|c|c|}
\hline \multirow{3}{*}{$\begin{array}{l}\text { Total petroleum system } \\
\text { and assessment units (AUs) }\end{array}$} & \multirow{3}{*}{$\begin{array}{l}\text { Field } \\
\text { Type }\end{array}$} & \multicolumn{6}{|c|}{$\begin{array}{c}\text { Historical drilling } \\
\text { (number of wells drilled each year) }^{1}\end{array}$} & \multirow{2}{*}{\multicolumn{4}{|c|}{$\begin{array}{c}\text { Co-requirements and co-production } \\
\text { for various possible annual drilling totals } \\
10 \text { wells }\end{array}$}} \\
\hline & & \multirow[b]{2}{*}{2011} & \multirow[b]{2}{*}{2012} & \multirow[b]{2}{*}{2013} & \multirow[b]{2}{*}{2014} & \multirow{2}{*}{\multicolumn{2}{|c|}{2015}} & & & & \\
\hline & & & & & & & & \multicolumn{2}{|c|}{$\begin{array}{c}\text { Required } \\
\text { water } \\
\text { (Mgal) }\end{array}$} & $\begin{array}{l}\text { Required } \\
\text { proppant } \\
\text { (10 }{ }^{3} \text { tons) } \\
\end{array}$ & $\begin{array}{c}\text { Flowback } \\
\text { water } \\
\text { (Mgal) }\end{array}$ \\
\hline \multicolumn{12}{|c|}{ Bakken Total Petroleum System } \\
\hline Elm Coulee-Billings Nose Continuous Oil AU & Oil & \begin{tabular}{l|l}
28 & \\
\end{tabular} & \begin{tabular}{l|l}
73 & \\
\end{tabular} & \begin{tabular}{l|l}
87 & \\
\end{tabular} & 79 & & 24 & & 43 & 26 & 3 \\
\hline Central Basin Continuous Oil AU & Oil & 392 & 593 & 476 & 515 & & 346 & & 43 & 26 & 3 \\
\hline Nesson-Little Knife Continuous Oil AU & Oil & 360 & 464 & 506 & 532 & & 428 & & 43 & 26 & 3 \\
\hline Eastern Transitional Continuous Oil AU & Oil & 189 & 226 & 210 & 155 & & 86 & & 43 & 26 & 3 \\
\hline Northwest Transitional Continuous Oil AU & Oil & 16 & 47 & 24 & 24 & & 23 & & 43 & 26 & 3 \\
\hline Three Forks Continuous Oil AU & Oil & 288 & 575 & 806 & 949 & & 639 & & 43 & 26 & 3 \\
\hline Total & & 1,273 & 1,978 & 2,109 & 2,254 & & 546 & & & & \\
\hline \multirow[b]{3}{*}{$\begin{array}{l}\text { Total petroleum system } \\
\text { and assessment units (AU) }\end{array}$} & \multicolumn{11}{|c|}{ Co-requirements and co-production for various possible annual drilling totals } \\
\hline & \multicolumn{3}{|c|}{100 wells } & \multicolumn{5}{|c|}{1,000 wells } & \multicolumn{3}{|c|}{5,000 wells } \\
\hline & $\begin{array}{c}\text { Required } \\
\text { water } \\
\text { (Mgal) }\end{array}$ & $\begin{array}{l}\text { Required } \\
\text { proppant } \\
\left(10^{3} \text { tons }\right)\end{array}$ & \begin{tabular}{|c|}
$\begin{array}{c}\text { Flowback } \\
\text { water } \\
\text { (Mgal) }\end{array}$ \\
\end{tabular} & \begin{tabular}{|c|c}
$\begin{array}{c}\text { Required } \\
\text { water } \\
\text { (Mgal) }\end{array}$ \\
\end{tabular} & $\begin{array}{l}\text { Req } \\
\text { prop } \\
\left(10^{3}\right. \\
\end{array}$ & & & & $\begin{array}{r}\text { Requi } \\
\text { wate } \\
\text { (Mga } \\
\end{array}$ & $\begin{array}{l}\text { Required } \\
\text { proppant } \\
\left(10^{3} \text { tons }\right)\end{array}$ & $\begin{array}{c}\text { Flowback } \\
\text { water } \\
\text { (Mgal) }\end{array}$ \\
\hline \multicolumn{12}{|c|}{ Bakken Total Petroleum System } \\
\hline Elm Coulee-Billings Nose Continuous Oil AU & 432 & 257 & 25 & 4,317 & 2,5 & & & & 21,58 & 12,844 & 1,250 \\
\hline Central Basin Continuous Oil AU & 432 & 257 & 25 & 4,317 & 2,5 & & & & 21,58 & 12,844 & 1,250 \\
\hline Nesson-Little Knife Continuous Oil AU & 432 & 257 & 25 & 4,317 & 2,5 & & & & 21,58 & 12,844 & 1,250 \\
\hline Eastern Transitional Continuous Oil AU & 432 & 257 & 25 & 4,317 & 2,5 & & & & 21,58 & 12,844 & 1,250 \\
\hline Northwest Transitional Continuous Oil AU & 432 & 257 & 25 & 4,317 & 2,5 & & & & 21,58 & 12,844 & 1,250 \\
\hline Three Forks Continuous Oil AU & 432 & 257 & 25 & 4,317 & 2,5 & & & & 21,58 & 12,844 & 1,250 \\
\hline
\end{tabular}

${ }^{1}$ From IHS Markit ${ }^{\mathrm{TM}}$ (2016).

categories: (1) agriculture (including use for irrigation, livestock, and aquaculture), (2) industrial (including mining and self-supplied industrial use), (3) municipal (public supply and self-supplied domestic use), and (4) thermoelectric (Maupin and others, 2014). Each of these volumes is the total production, withdrawal, or use within the map area of each AU. Because the Three Forks Continuous Oil AU spatially overlaps the Bakken continuous AUs (the Three Forks Formation underlies the Bakken Formation), the water quantities indicated for the Three Forks Continuous Oil AU are also included within the overlying Bakken Continuous Oil AUs.

Table 5 provides information to facilitate comparisons between the Bakken and Three Forks AUs and comparisons between these AUs and areas to be studied in future USGS water and proppant assessments.
Listed in the table are the estimated water and proppant requirements, and flowback water and total produced water production, per barrel of undiscovered, technically recoverable oil in each AU. Each of these numbers is based on the mean value of the relevant distributions, and for completeness, the mean value of the estimated undiscovered oil resources in each AU (Gaswirth and others, 2013) is also shown.

\section{Acknowledgments}

The authors thank Karen Jenni, Cheryl Woodall, and Katie Walton-Day (USGS) for helpful comments and discussions and Dave Hvinden and Dave McCusker (North Dakota Industrial Commission) for discussion and providing hydraulic fracturing data. 
Table 4. Water quantities produced, withdrawn, and used for various purposes within the area of each assessment unit (AU). Note that because the Three Forks Continuous Oil AU occupies the same map area as the other AUs, the water quantities listed for the Three Forks Continuous Oil AU include the quantities listed for the other AUs.

[Mgal, million gallons]

\begin{tabular}{|c|c|c|c|c|c|c|c|}
\hline \multirow{2}{*}{$\begin{array}{l}\text { Total petroleum system } \\
\text { and assessment units (AU) }\end{array}$} & \multirow{2}{*}{$\begin{array}{l}\text { Oil/gas total produced water' } \\
\text { (mean annual production, } \\
\text { 2011-2015, total for all producing } \\
\text { formations within AU map area) } \\
\text { (Mgal) }\end{array}$} & \multirow{2}{*}{\begin{tabular}{|c|} 
Surface water \\
Withdrawal \\
(annual total, 2010) \\
(Mgal)
\end{tabular}} & \multirow{2}{*}{\begin{tabular}{|c|}
$\begin{array}{c}\text { Ground- } \\
\text { water }^{2}\end{array}$ \\
$\begin{array}{c}\text { Withdrawal } \\
\text { (annual total, 2010) } \\
\text { (Mgal) }\end{array}$ \\
\end{tabular}} & \multicolumn{4}{|c|}{$\begin{array}{c}\text { Water use }^{2} \\
\text { (annual total, 2010) }\end{array}$} \\
\hline & & & & $\begin{array}{c}\text { Agriculture } \\
\text { (Mgal) }\end{array}$ & $\begin{array}{c}\text { Industrial } \\
\text { (Mgal) }\end{array}$ & $\begin{array}{c}\text { Municipal } \\
\text { (Mgal) }\end{array}$ & $\begin{array}{l}\text { Thermo- } \\
\text { electric } \\
\text { (Mgal) }\end{array}$ \\
\hline \multicolumn{8}{|c|}{ Bakken Total Petroleum System } \\
\hline Elm Coulee-Billings Nose Continuous Oil AU & 1,191 & 60,760 & 1,289 & 53,681 & 656 & 394 & 7,318 \\
\hline Central Basin Continuous Oil AU & 4,018 & 49,740 & 4,863 & 50,072 & 905 & 1,307 & 2,319 \\
\hline Nesson-Little Knife Continuous Oil AU & 4,360 & 4,587 & 2,563 & 5,421 & 1,185 & 544 & 0 \\
\hline Eastern Transitional Continuous Oil AU & 1,793 & 10,584 & 1,166 & 1,169 & 879 & 429 & 9,272 \\
\hline Northwest Transitional Continuous Oil AU & 914 & 18,387 & 6,765 & 24,082 & 450 & 620 & 0 \\
\hline Three Forks Continuous Oil AU & 14,687 & 485,359 & 29,525 & 182,259 & 11,580 & 10,109 & 310,937 \\
\hline
\end{tabular}

${ }^{1}$ From IHS Markit ${ }^{\mathrm{TM}}$ (2016).

${ }^{2}$ From Maupin and others (2014).

Table 5. Water demand and production and proppant demand per unit of undiscovered, technically recoverable petroleum based on mean values of the assessment outputs. The bottom row of this table shows the mean value across all six assessment units, weighted by the volume of undiscovered, technically recoverable oil.

[mmbo, million barrels of oil; Mgal, million gallons. Gray shading indicates not applicable]

\begin{tabular}{|c|c|c|c|c|c|c|}
\hline \multirow[t]{2}{*}{$\begin{array}{c}\text { Total petroleum system } \\
\text { and assessment units (AUs) }\end{array}$} & \multirow[t]{2}{*}{$\begin{array}{l}\text { Field } \\
\text { type }\end{array}$} & $\begin{array}{c}\text { Total } \\
\text { undiscovered oil' } \\
\text { (mmbo) }\end{array}$ & $\begin{array}{c}\text { Water } \\
\text { requirement per oil } \\
\text { (Mgal/mmbo) }\end{array}$ & \begin{tabular}{|c|} 
Proppant \\
requirement per oil \\
$\left(10^{3}\right.$ tons $\left./ \mathrm{mmbo}^{\prime}\right)$ \\
\end{tabular} & $\begin{array}{l}\text { Flowback water } \\
\text { production per oil } \\
\text { (Mgal/mmbo) }\end{array}$ & $\begin{array}{c}\text { Total produced } \\
\text { water per oil } \\
\text { (Mgal/mmbo) }\end{array}$ \\
\hline & & Mean & Mean & Mean & Mean & Mean \\
\hline \multicolumn{7}{|c|}{ Bakken Total Petroleum System } \\
\hline Elm Coulee-Billings Nose Continuous Oil AU & Oil & 283 & 35 & 21 & 2.0 & 46 \\
\hline Central Basin Continuous Oil AU & Oil & 1,122 & 22 & 13 & 1.3 & 51 \\
\hline Nesson-Little Knife Continuous Oil AU & Oil & 1,149 & 18 & 10 & 1.0 & 31 \\
\hline Eastern Transitional Continuous Oil AU & Oil & 883 & 16 & 10 & 1.0 & 80 \\
\hline Northwest Transitional Continuous Oil AU & Oil & 207 & 47 & 28 & 2.7 & 143 \\
\hline Three Forks Continuous Oil AU & Oil & 3,731 & 24 & 15 & 1.4 & 56 \\
\hline Weighted mean & & & 23 & 14 & 1.3 & 56 \\
\hline
\end{tabular}

${ }^{1}$ From Gaswirth and others (2013).

\section{References Cited}

Charpentier, R.R., and Cook, T.A., 2010, Improved USGS methodology for assessing continuous petroleum resources (ver. 2.0, November 9 , 2012): U.S. Geological Survey Data Series 547, 22 p. and program, accessed May 31, 2017, at https://pubs.usgs.gov/ds/547/.

Gaswirth, S.B., and Marra, K.R., 2015, U.S. Geological Survey 2013 assessment of undiscovered resources in the Bakken and Three Forks Formations of the U.S. Williston Basin Province: AAPG Bulletin, v. 99, no. 4, p. 639-660.

Gaswirth, S.B., Marra, K.R., Cook, T.A, Charpentier, R.R., Gautier, D.L., Higley, D.K., Klett, T.R., Lewan, M.D., Lillis, P.G., Schenk, C.J., Tennyson, M.E., and Whidden, K.J., 2013, Assessment of undiscovered oil resources in the Bakken and Three Forks Formations, Williston Basin Province, Montana, North Dakota, and South Dakota, 2013: U.S. Geological Survey Fact Sheet 2013-3013, 4 p., accessed May 31, 2017, at https://pubs.usgs.gov/fs/2013/3013/.

Haines, S.S., 2015, Methodology for assessing quantities of water and proppant injection, and water production associated with development of continuous petroleum accumulations: U.S. Geological Survey Open-File Report 2015-1117, 18 p., accessed May 31, 2017, at https://doi.org/10.3133/ofr20151117.

IHS Markit ${ }^{\mathrm{TM}}$, 2016, US Well History and Production Database: Englewood, Colo., IHS Markit ${ }^{\mathrm{TM}}$, accessed August 2016 at http://www.ihsenergy.com. [Available from IHS Markit ${ }^{\mathrm{TM}}, 15$ Inverness Way East, Englewood, CO 80112.]

Maupin, M.A., Kenny, J.F., Hutson, S.S., Lovelace, J.K., Barber, N.L., and Linsey, K.S., 2014, Estimated use of water in the United States in 2010: U.S. Geological Survey Circular 1405, 56 p., accessed May 31, 2017, at https://doi.org/10.3133/cir1405.

\section{For More Information}

Assessment results are available at the USGS Energy Resources Program website at https://energy.usgs.gov.

\section{Bakken and Three Forks Water and Proppant Assessment Team}

Seth S. Haines, Brian A. Varela, Sarah J. Hawkins, Nicholas J. Gianoutsos, Joanna N. Thamke, Mark A. Engle, Marilyn E. Tennyson, Christopher J. Schenk, Stephanie B. Gaswirth, Kristen R. Marra, Scott A. Kinney, Tracey J. Mercier, and Cericia D. Martinez 